\title{
OPEN Author Correction: BsmR degrades c-di-GMP to modulate biofilm formation of nosocomial pathogen Stenotrophomonas maltophilia
}

\author{
Wei Liu ${ }^{1,2}$, Xiu-Qi Tian ${ }^{2,3}$, Jin-Wei Wei ${ }^{2,3}$, Li-Li Ding ${ }^{2,3}$, Wei Qian ${ }^{2}{ }^{2}$, Zhong Liu ${ }^{1}$ \& \\ Fang-Fang Wang ${ }^{2}$
}

Correction to: Scientific Reports https://doi.org/10.1038/s41598-017-04763-w, published online 05 July 2017

This Article contains typographical errors in the Acknowledgements section.

"The work was financially supported by National Natural Science Foundation of China (grant 3140071), and the Strategic Priority Research Program of the Chinese Academy of Sciences (grant XDB11040700)."

should read:

"The work was financially supported by National Natural Science Foundation of China (grant 31400071), and the Strategic Priority Research Program of the Chinese Academy of Sciences (grant XDB11040700).”

\begin{abstract}
(c) (i) Open Access This article is licensed under a Creative Commons Attribution 4.0 International (c) License, which permits use, sharing, adaptation, distribution and reproduction in any medium or format, as long as you give appropriate credit to the original author(s) and the source, provide a link to the Creative Commons license, and indicate if changes were made. The images or other third party material in this article are included in the article's Creative Commons license, unless indicated otherwise in a credit line to the material. If material is not included in the article's Creative Commons license and your intended use is not permitted by statutory regulation or exceeds the permitted use, you will need to obtain permission directly from the copyright holder. To view a copy of this license, visit http://creativecommons.org/licenses/by/4.0/.
\end{abstract}

(C) The Author(s) 2019

\footnotetext{
${ }^{1}$ School of Pharmacy, Shanghai Jiao Tong University, Shanghai, 200240, China. ${ }^{2}$ State Key Laboratory of Plant Genomics, Institute of Microbiology, Chinese Academy of Sciences, Beijing, 100101, China. ${ }^{3}$ School of Life Sciences, University of Chinese Academy of Sciences, Beijing, 100049, China. Correspondence and requests for materials should be addressed to Z.L. (email: liuzhong@sjtu.edu.cn) or F.-F.W. (email:wangff@im.ac.cn)
} 